\title{
Four-Electron Oxygen Reduction by Tetrathiafulvalene
}

\author{
Astrid J. Olaya, ${ }^{\dagger}$ Peiyu Ge, ${ }^{\dagger}$ Jérôme F. Gonthier, ${ }^{\S}$ Peter Pechy, ${ }^{\ddagger}$ Clémence Corminboeuf, ${ }^{\S}$ and \\ Hubert H. Girault ${ }^{*,+}$
}

${ }^{\dagger}$ Laboratoire d'Electrochimie Physique et Analytique and ${ }^{\ddagger}$ Laboratoire de Photonique et InterfacesStation 6, and

${ }^{\S}$ Laboratory for Computational Molecular Design, Ecole Polytechnique Fédérale de Lausanne, CH-1015 Lausanne, Switzerland

Supporting Information

ABSTRACT: The four-electron reduction of oxygen by tetrathiafulvalene (TTF) in acidified 1,2-dichloroethane and at the acidified water/1,2-dichloroethane interface has been observed. Spectroscopy and ion transfer voltammetry results suggest that the reaction proceeds by the fast protonation of TTF followed by the 4-electron reduction of oxygen to form water. Electronic structure computations give evidence of the formation of a helical tetramer assembly $\left(\left[\mathrm{TTF}_{4} \mathrm{H}_{2}\right]^{2+}\right)$ of two protonated TTF and two neutral TTF molecules. The protonated tetramer is potentially able to deliver the four electrons needed for the oxygen reduction. The production of water was corroborated by
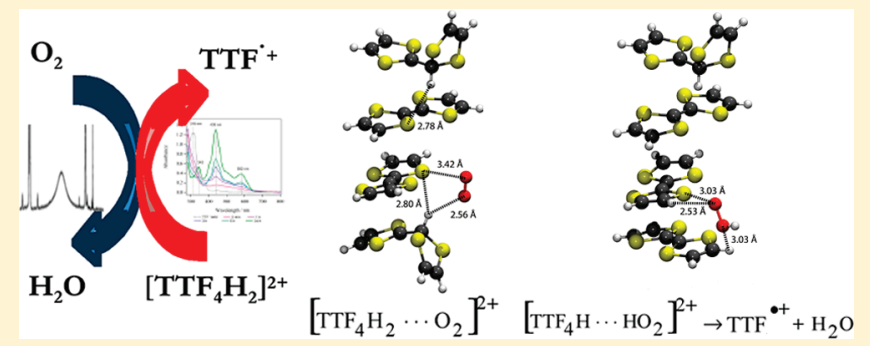

${ }^{1} \mathrm{H}$ NMR analysis.

\section{INTRODUCTION}

The reduction of oxygen to water is a key reaction of the respiratory chain of aerobic organisms. ${ }^{1-3}$ In eukaryotes, the enzyme cytochrome $c$ oxidase or complex IV, is the last enzyme in the respiratory electron transport chain of mitochondria, and its function is the four-electron reduction of oxygen to water. ${ }^{1-4}$ The energy evolved in this catalytic reaction generates a transmembrane proton transport and an electrochemical potential gradient that finally drives the synthesis of the energy-rich ATP. ${ }^{1,5}$ From a technological standpoint, the oxygen reduction reaction (ORR) is a key step for the development of efficient fuel cells. The most widely used electrocatalysts in fuel cells are based on precious metal nanoparticles supported on high area carbon materials. To circumvent the use of these rare metals, the search for molecular catalysts has been very active over the last decades. Among these molecular systems, complexes of transition metals with macrocyclic ligands like porphyrins and phthalocyanines have been widely studied where the metal center is used to bind oxygen. ${ }^{2,3,6-10}$ In most cases, oxygen reduction proceeds via a two-electron process to $\mathrm{H}_{2} \mathrm{O}_{2}$, a strong oxidizing agent having deleterious effects on the catalyst itself. Therefore, different strategies have been proposed to drive the reaction via the four-electron process to water. One approach consists in using bimetallic catalysts where the oxygen molecule binds between the two metal atoms. As a result the $\mathrm{O}-\mathrm{O}$ bond is activated, and the protonation and formation of peroxo-type intermediates is hindered, as for example in Pacman porphyrins. ${ }^{2,3,6-9,11-14}$ Alternatively, monometallic systems can be used with some functional groups to adjust the $\mathrm{p} K_{\mathrm{a}}$ of dioxygen adducts in order to promote proton-coupled, multi-electron transfer reactions, as for example in the Hangman porphyrins. ${ }^{15}$

Recently, Ndamanisha et al. reported the synthesis of a mesoporous carbon/tetrathiafulvalene composite in which the electron donor properties of tetrathiafulvalene (TTF) are used to enhance the performance of the nanostructured matrix of ordered mesoporous carbon (OMC) toward the direct four-electron reduction of oxygen. ${ }^{16}$ TTF is an organic electron donor extensively studied in the fields of organic conductors, ${ }^{17-20}$ superconductors, ${ }^{19,21,22}$ sensors, ${ }^{19,23}$ photovoltaic cells ${ }^{24}$ and solar cells, ${ }^{25}$ and even for the fabrication of molecular machines, liquid crystals, and gels. ${ }^{18,22}$ This sulfur-containing $\pi$-electron molecule is often used as a building block in the synthesis of highly electrically conducting assembled structures. ${ }^{19,22}$ The oxidation of the neutral TTF shows two reversible and wellseparated one-electron oxidation steps: the formation of the cationic radical and dicationic species. ${ }^{18-20,23,26-28}$ This behavior promotes the characteristic intramolecular charge transfer (ICT) phenomena of the oxidized TTF derivatives at the ground state. $^{19}$

We have recently shown that the interface between two immiscible electrolyte solutions (ITIES) provides an interesting interface to study proton-coupled electron transfer reactions involving aqueous protons and lipophilic electron donors. This polarized interface can be studied by electrochemical methods using a four-electrode potentiostat and a cell comprising two reference electrodes to control the polarization of the interface and two counter electrodes that provide the current. Alternatively, the polarization of the interface can be controlled chemically by a judicious choice of supporting electrolytes, the distribution of which imposes the Galvani potential difference between the two phases. In particular, we can use this approach to study oxygen reduction. For example, it has been shown that oxygen could be reduced to hydrogen peroxide at the interface between an aqueous

Received: April 8, 2011

Published: June 29, 2011 
Scheme 1. Initial Composition of the Aqueous and Organic Phases for the Two-Phase Reactions

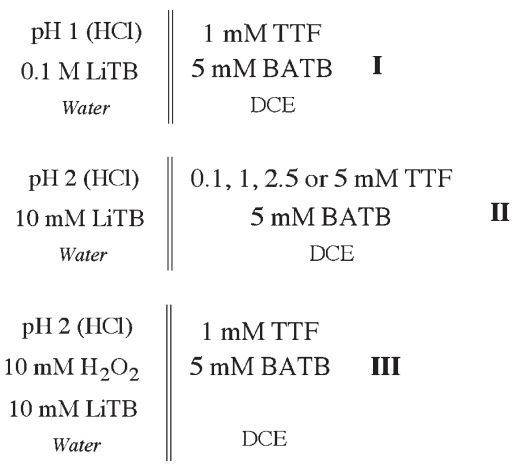

acidic solution and 1,2-dichloroethane containing decamethylferrocene as electron donor. ${ }^{29-33}$ Also, we have shown that both lipophilic cobalt ${ }^{29,30,34}$ and free base porphyrins ${ }^{35}$ can be used to catalyze the interfacial reduction of oxygen by ferrocene, which reacts very slowly with $\mathrm{O}_{2}$ in the absence of catalysts. In all the cases the selectivity toward $\mathrm{H}_{2} \mathrm{O}_{2}$ is high.

In this work, the reduction of oxygen by tetrathiafulvalene (TTF) in 1,2-dichloroethane and at an ITIES (water/1,2dichloroethane) has been studied. Ion transfer voltammetry and UV-visible spectroscopy under aerobic conditions show the formation of the stable radical cation $\mathrm{TTF}^{\circ+}$, indicating that TTF can reduce oxygen. The analysis of the products of the reaction shows that the concentration of $\mathrm{H}_{2} \mathrm{O}_{2}$ is less than $3 \%$ of the expected value, implying that more than $97 \%$ of TTF is performing the four-electron reduction to water. UV-visible spectroscopic analyses suggest the protonation of TTF as the first stage of the reaction. Electronic structure computations give evidence for the formation of a helical tetramer $\left(\left[\mathrm{TTF}_{4} \mathrm{H}_{2}\right]^{2+}\right)$ by the interaction between two protonated TTF and two neutral TTF. The tetramer is potentially able to deliver the four electrons needed for the oxygen reduction to water. The production of $\mathrm{H}_{2} \mathrm{O}$ was confirmed by ${ }^{1} \mathrm{H}$ NMR in performing oxygen reduction in dry acidic organic solvents. In other words, this work represents the first demonstration of the four-electron reduction of oxygen by tetrathiafulvalene in solution in the presence of protons.

\section{EXPERIMENTAL SECTION}

2.1. Chemicals. All solvents and chemicals were used as received without further purification. Bis(triphenylphosphoranylidine)ammonium chloride (BACl 98\%), lithium tetrakis(pentafluorophenyl)borate ethyl etherate ( $\mathrm{LiTB}$ purum) and lithium chloride $(\mathrm{LiCl}>99 \%)$ were purchased from Fluka. Hydrochloric acid (37-38\%) and 1,2-dicholoroethane (DCE grade HPLC) were purchased from Merck and Applichem, respectively. Tetrathiafulvalene (TTF, 99+\%), sodium iodide (NaI, 99+\%), and toluene $(99.5 \%)$ were purchased from Acros. Deuterated 1,2-dichloroethane (DCE- $\left.d_{4}\right)$ was purchased from Aldrich.

Bis(triphenylphosphoranylidine)ammonium tetrakis(pentafluorophenyl)borate (BATB) was prepared by metathesis of $1: 1$ mixture of $\mathrm{BACl}$ and LiTB in methanol/water $(\mathrm{V}: \mathrm{V}=2: 1)$, followed by recrystallization from acetone. ${ }^{36}$

2.2. Two-Phase Reactions. Two-phase reactions were performed in glass flasks with a volume of $4 \mathrm{~mL}(2 \mathrm{~mL}$ each phase $)$ under stirring at $900 \mathrm{rpm}$. The initial composition of the aqueous and organic phase is illustrated in the cells I-III (Scheme 1). At the end of the reaction, the aqueous and organic solutions were isolated from each other and analyzed.
Scheme 2. Composition of the Ion Transfer Voltammetry Cells

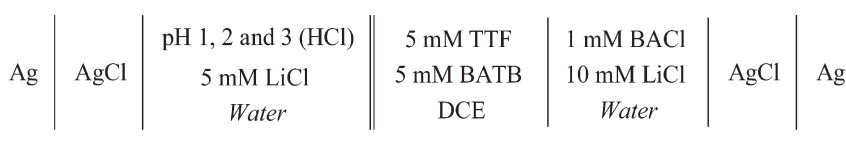

Scheme 3. Initial Composition of the Biphasic System Used to Synthesize the Organic Acid HTB

\begin{tabular}{c||c}
$\mathrm{pH} 2(\mathrm{HCl})$ & \\
$10 \mathrm{mM} \mathrm{LiTB}$ & $5 \mathrm{mM}$ BATB \\
Water & DCE
\end{tabular}

The organic phase was directly subjected to UV-visible spectroscopic analyses in order to follow the formation of the radical cation $\mathrm{TTF}^{\bullet+}$, while the aqueous phase was treated with $\mathrm{NaI}$ in excess (equivalent to $0.1 \mathrm{M}$ ) prior to UV-visible spectroscopic measurements in order to detect the formation of $\mathrm{I}_{3}^{-}$resulting from the oxidation of $\mathrm{I}^{-}$by $\mathrm{H}_{2} \mathrm{O}_{2}$. The UV-visible spectroscopic analyses were performed using an Ocean Optical CHEM2000 spectrophotometer. For the analysis of the organic phase, the path length of the quartz cell was $1 \mathrm{~mm}$, while for the aqueous phase it was $10 \mathrm{~mm}$. All the experiments under aerobic conditions were performed with air-saturated solutions at an ambient temperature $\left(23 \pm 2{ }^{\circ} \mathrm{C}\right)$.

The experiments under anaerobic conditions were carried out in a glovebox purged by nitrogen, after degasification of all the solutions with nitrogen.

2.3. Ion Transfer Voltammetry Measurements at ITIES. Determination of the Standard Transfer Potential of TTF ${ }^{\circ+}$. Ion transfer voltammetric measurements at the water/DCE interface were performed in a four-electrode cell following the configuration described previously for Hatay et al., ${ }^{37}$ with two reference electrodes to polarize the interface and two platinum counter electrodes to provide the current. A commercial potentiostat (PGSTAT 30, Metrohm, CH) was used. The external potential was applied by means of two silver/ silver chloride $(\mathrm{Ag} / \mathrm{AgCl})$ reference electrodes, which were connected to the aqueous and DCE phases, respectively, by means of a Luggin capillary. The electrochemical cell composition is illustrated in Scheme 2. The Galvani potential difference, $\Delta_{\mathrm{o}}^{\mathrm{w}} \phi$, was estimated by taking the formal ion transfer potential of $\mathrm{TMA}^{+}$as $0.17 \mathrm{~V}^{36}$

2.4. Determination of the Water Content by ${ }^{1} \mathrm{H}$ NMR Analyses. When carrying out the reaction in a biphasic system, the organic phase is completely saturated with water, and quantification of water production is thus not possible. Therefore, to quantify the formation of water by ${ }^{1} \mathrm{H} \mathrm{NMR}$, the reaction between the organic acid HTB and TTF was performed in a single DCE- $d_{4}$ phase.

First, the synthesis of the organic acid HTB was carried out using the biphasic system illustrated in Scheme 3 ( $2 \mathrm{~mL}$ each phase) in which the aqueous $\mathrm{TB}^{-}$is acting as a phase transfer catalyst to extract protons to the organic phase as HTB. $\mathrm{BA}^{+}$was used as a reference compound in order to estimate the concentration of water by ${ }^{1} \mathrm{H}$ NMR. The system was stirred during $1 \mathrm{~h}$ at $900 \mathrm{rpm}$. After formation of HTB, the two phases were isolated from each other, and the organic phase was dried by azeotropic drying with toluene in order to remove the excess water. The dried HTB+BATB was dissolved in DCE- $d_{4}\left((\mathrm{HTB}+\mathrm{BATB}) / \mathrm{DCE}-d_{4}\right)$.

Finally, the one-phase reaction was performed dissolving TTF, which was previously kept in a desiccator under vacuum during one week, in the (HTB+BATB)/DCE- $d_{4}$ solution (5 mM TTF). The ${ }^{1} \mathrm{H}$ NMR spectra of the reaction mixture were recorded using a Bruker Avance- 400 $\mathrm{MHz}$ NMR spectrometer. 
Two more solutions were tested at the same time as control experiments: ( $5 \mathrm{mM}$ TTF $+5 \mathrm{mM} \mathrm{BATB})$ in DCE- $d_{4}$ and dried (HTB+BATB) in DCE- $d_{4}$. The content of water obtained in these two solutions was subtracted from the content of water of the reacting vial.

2.5. Computational Details. The reaction path was computed using two different DFT methods: the M06- $2 \mathrm{X}^{38}$ functional, parametrized for improving the description of weak interactions, and B3LYP-dDsC in which the recently developed dispersion correction, $\mathrm{dDsC},,^{39,40}$ is added to B3LYP. ${ }^{41,42}$ The dDsC correction, which uses both density-dependent dispersion coefficients and damping factors, gives highly accurate reaction, conformation, as well as binding energies. ${ }^{39,40}$ The energies were computed at the M06-2X/cc-pVTZ ${ }^{43,44} / / \mathrm{M} 06-2 \mathrm{X} / \mathrm{SVP}^{45}$ and at B3LYP-dDsC/6-31+G G $^{* * 6-49} / /$ B3LYP-dDsC/6-31G** levels of theory (energy//geometry). All B3LYP-dDsC computations were performed in Q-Chem ${ }^{50}$ (version 3.2) using a grid with 75 radial points and 302 angular points, roughly corresponding to the default "Fine" grid in Gaussian09. ${ }^{51}$ B3LYP-dDsC geometries were optimized in the gas phase, and single-point energies were computed with the $\mathrm{SM} 8^{52}$ solvation model for 1,2-dichloroethane (note that the current Q-Chem implementation of the SM8 solvation model is compatible with only three basis set types that include $\left.6-31+\mathrm{G}^{* *}\right)$. M06-2X computations were performed in Gaussian $09^{51}$ using the Fine grid for geometry optimizations in the gas phase and the Ultrafine grid (M06 functionals have been shown to be especially sensitive to the grid ${ }^{53}$ ) for single-point energy computations in the solvent. 1,2-Dichloroethane was modeled in Gaussian using the IEFPCM implicit solvation. ${ }^{54}$ Minima and transition states on the potential energy surface were characterized by frequency computations, which were used to compute zero-point and thermal contributions to single-point energies. Unrestricted formalism was employed for all oxygen- or radical-containing species. Stability checks were performed ${ }^{55,56}$ for cases for which closed or open-shell singlet electronic configurations are possible.

Interaction enthalpies correspond to enthalpy (at $298 \mathrm{~K}$ ) differences between a complex and its separated optimized adducts at their lowest spin state (i.e., triplet for $\mathrm{O}_{2}$ ). The energies are corrected for the basis set superposition error using the Boys and Bernardi scheme ${ }^{57}$ on monomers frozen at the complex geometry. Since neither $\mathrm{dDsC}$ nor SM8 supports ghost atoms in current Q-Chem implementations, B3LYP-dDsC BSSE corrections were approximated by the corresponding B3LYP number. M06-2X BSSE corrections were obtained in the gas phase since the IEFPCM model also does not support ghost atoms.

NMR computations at the GIAO ${ }^{58,59} \mathrm{~B} 3 \mathrm{LYP} / 6-311+\mathrm{G}(2 \mathrm{~d}, \mathrm{p})^{49,60-62} / /$ M06-2X/SVP level were referenced to TMS and compared to experiment.

Conformational searches were conducted on the dimers of TTF and the protonated counterpart, $\mathrm{TTFH}^{+}$, using a random search procedure ${ }^{63-65}$ to generate different relative orientations of the two monomers.

\section{RESULTS AND DISCUSSION}

Under aerobic conditions, as soon as an acidified aqueous solution containing the lipophilic anion $\mathrm{TB}^{-}$able to pump aqueous protons to the organic phase (cell I, Scheme 1 : TFF $=1 \mathrm{mM}, \mathrm{pH}=1$ ) is contacted with a solution of TTF in 1,2-dichloroethane, the color of the organic phase changes from yellow to pink and progressively turns dark red, suggesting the formation of the radical cation $\mathrm{TTF}^{\circ+}$. In order to corroborate the oxidation of TTF, the evolution of the reaction with time was followed by UV-visible spectroscopic analysis of the organic phase (as described in the Experimental Section). Figure 1 shows the absorption spectrum of neutral TTF centered at $316 \mathrm{~nm}$, and the absorption spectra obtained after reaction with bands centered at 343, 439, and $582 \mathrm{~nm}$ that correspond to the formation of $\mathrm{TTF}^{\bullet+27,28,66}$ indicating that TTF has been oxidized. There is no evidence for the formation of TTF dications $\left(\lambda_{\max } \cong 380 \mathrm{~nm}\right)^{26,67}$ or dimeric radical cations

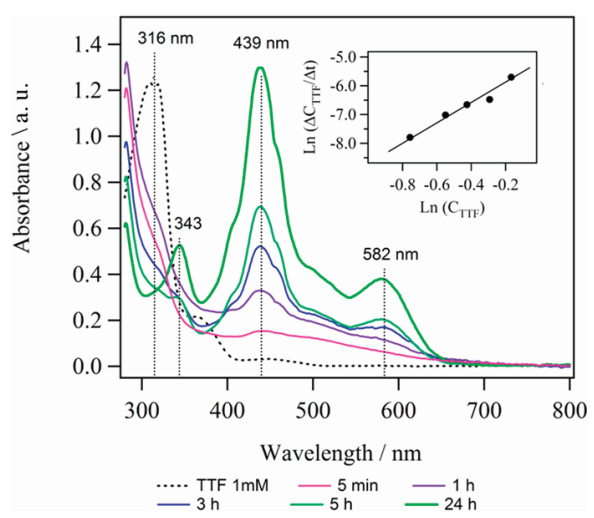

Figure 1. UV-visible spectroscopic analyses of the organic phase after biphasic reaction (cell I, Scheme 1 : TTF $=1 \mathrm{mM}, \mathrm{pH}=1$ ). (Inset) Analysis of the UV-visible spectroscopic data.

$\left(\lambda_{\max } \cong 600-800 \mathrm{~nm}\right){ }^{26,28,68,69}$ The absence of dimeric radical cations of TTF is expected, taking into account that those species are highly unstable at room temperature, and therefore, they have been observed only at very low temperatures or after encapsulation in the cavity of highly ordered organic molecules, ${ }^{26,28,68,69}$

By comparing the standard redox potentials of the $\mathrm{O}_{2} / \mathrm{H}_{2} \mathrm{O}_{2}$ and $\mathrm{O}_{2} / \mathrm{H}_{2} \mathrm{O}$ couples in DCE $(1.17$ and $1.75 \mathrm{~V}$, respectively, vs $\mathrm{SHE})^{37}$ with that of the $\mathrm{TTF}^{\bullet+} / \mathrm{TTF}$ couple $(0.56 \mathrm{~V}$ vs SHE Figure S1, Supporting Information [SI]), it is clear that the oxygen reduction reaction by TTF is thermodynamically feasible.

The reaction was followed until the absorbance of the band of the radical cation at $439 \mathrm{~nm}^{27,28,66}$ stops increasing, indicating the end of the reaction. In order to estimate the time evolution of the reaction, we assumed at this point that all the neutral TTF was consumed following either eqs 1 or 2 . In this way, the order and the rate constant of the reaction with respect to TTF at $\mathrm{pH}=1$ was estimated to be 3 and $5.3 \times 10^{-3} \mathrm{~L}^{2} \mathrm{mmol}^{-2}$. $\min ^{-1}$, respectively (Figure 1 ). It is important to note that no changes were observed in the reaction products after one month, indicating that the radical cation formed by this reaction is highly stable.

$$
\begin{aligned}
& 2 \mathrm{TTF}+2 \mathrm{H}_{3} \mathrm{O}^{+}+\mathrm{O}_{2} \rightarrow 2 \mathrm{TTF}^{+}+\mathrm{H}_{2} \mathrm{O}_{2}+2 \mathrm{H}_{2} \mathrm{O} \\
& 4 \mathrm{TTF}+4 \mathrm{H}_{3} \mathrm{O}^{+}+\mathrm{O}_{2} \rightarrow 4 \mathrm{TTF}^{+}+6 \mathrm{H}_{2} \mathrm{O}
\end{aligned}
$$

A more detailed analysis of the UV-visible spectra (Figure 1) shows that after $5 \mathrm{~min}$ of reaction the absorbance of the neutral TTF decreases around $52 \%$ but just $11 \%$ of $\mathrm{TTF}^{\bullet+}$ was produced, suggesting the presence of other reaction intermediates. Taking into account that TTF also could react with protons, the same reaction was performed under anaerobic conditions. Figure 2 shows the comparison of the UV-visible spectrum after reaction under aerobic and under anaerobic conditions (cell II, Scheme 1: $\mathrm{TTF}=1 \mathrm{mM}, \mathrm{pH}=2$ ).

In both cases after $5 \mathrm{~min}$ of reaction, the absorbance of the neutral TTF decreases around 52\%, indicating that such decrease is not related to the reduction of oxygen but to the protonation of TTF following eq 3. In accordance with Giffard et al. ${ }^{17,70}$ the protonation of TTF takes place at the central carbon-carbon bond rather than at the electron-rich sulfur atoms. Under anaerobic conditions the absorption bands corresponding to $\mathrm{TTF}^{\bullet+}$ were also observed; however, the absorbance is much lower than under aerobic conditions. In the absence of oxygen, the radical 


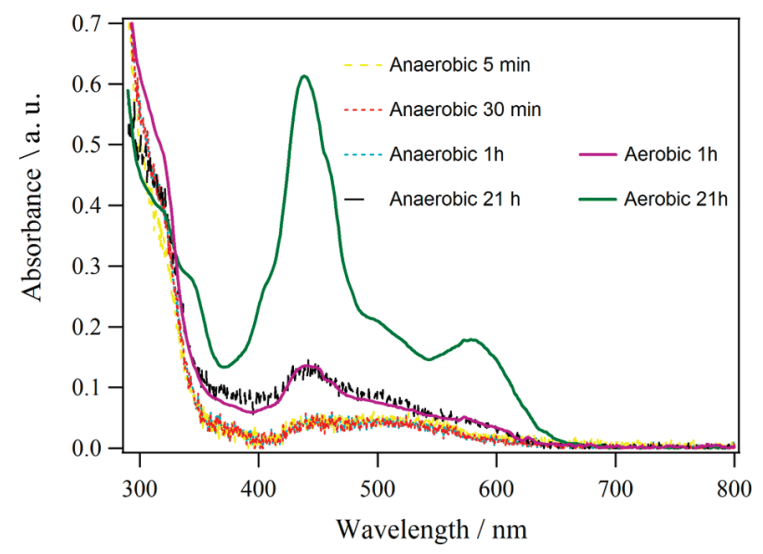

Figure 2. UV-visible spectra of the organic phase after biphasic reaction (cell II, Scheme 1: TTF $=1 \mathrm{mM}, \mathrm{pH}=2$ ) under aerobic and anaerobic conditions.

cation could be formed by the reaction between protonated TTF and neutral TTF (eq 4), as suggested by Giffard et al. ${ }^{17,70}$ The fact that the production of $\mathrm{TTF}^{\circ+}$ under aerobic conditions is much faster than under anaerobic conditions indicates that the first reaction is related to the reduction of oxygen. It also suggests that protonated TTF is an intermediate that probably reacts with oxygen instead of neutral TTF.
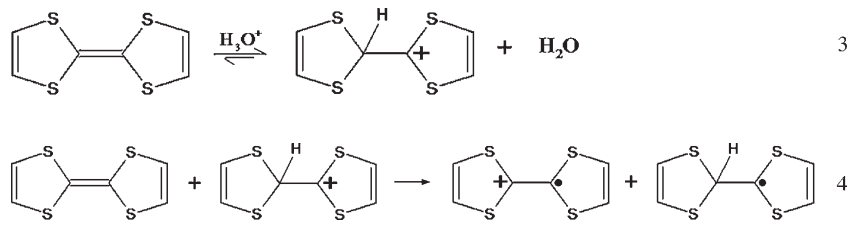

From those spectroscopic measurements, a mechanism in which neutral TTF reacts fast with protons to form protonated TTF (eq 5) and then the protonated species react with oxygen (either eqs 6 or 7) can be proposed. Assuming that the reaction 5 is in equilibrium, its rate will be dependent on the concentration of the neutral TTF, protonated $\mathrm{TTFH}^{+}$, and protons (eq 5). Since oxygen is in excess, the rates of reactions 6 and 7 will depend on the concentration of $\mathrm{TTFH}^{+}$, which from eq 5 can be expressed in terms of the concentration of neutral TTF and protons. Therefore, the overall reaction rate should depend on the concentration of TTF and protons (eq 8).

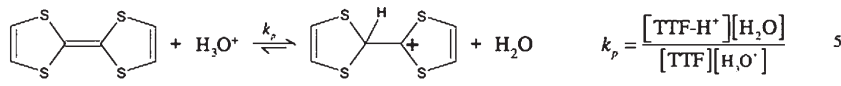

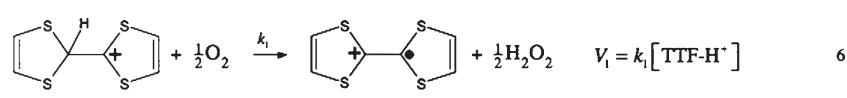

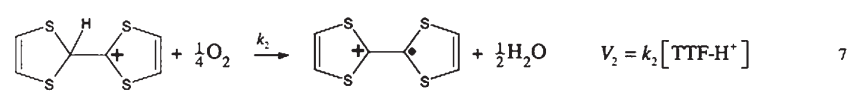

$$
\begin{aligned}
& V_{1,2}=k_{1,2} k_{p} \frac{[\mathrm{TTF}]\left[\mathrm{H}, \mathrm{O}^{\circ}\right]}{\left[\mathrm{H}_{2} \mathrm{O}\right]}
\end{aligned}
$$

In order to probe the suggested mechanism, the evolution of the reaction at $\mathrm{pH}=2$ was also performed using cell II illustrated in Scheme 1 ( $1 \mathrm{mM} \mathrm{TFF})$. The UV-visible spectra of the organic phase are displayed in the Figure $3 \mathrm{a}$. The reaction order with respect to TTF at $\mathrm{pH}=2$ was determined to be 1 , and the rate constant, $6.1 \times 10^{-4} \mathrm{~min}^{-1}$ (Figure 3a). The change in the
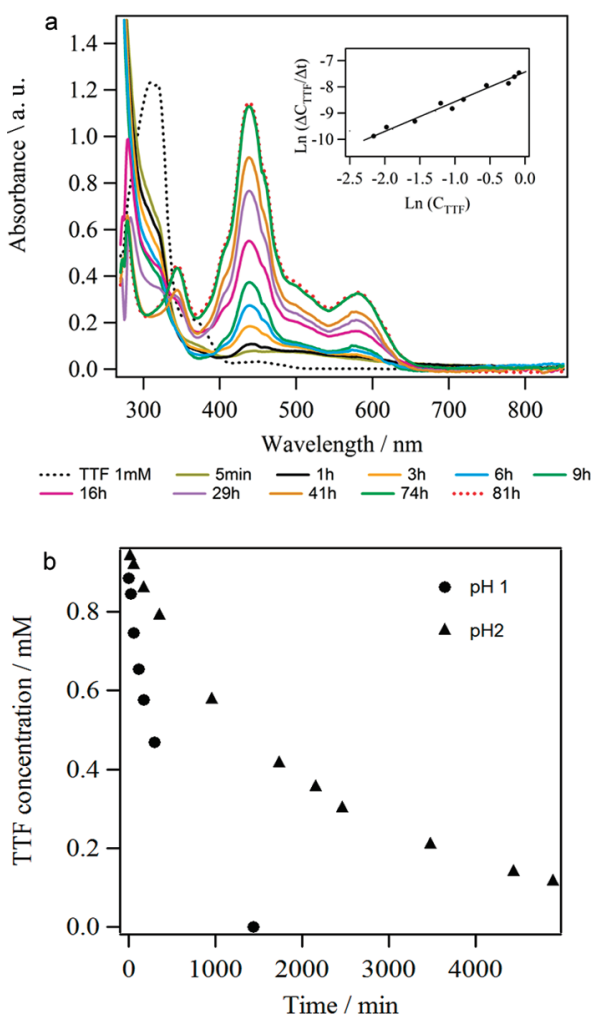

Figure 3. (a) UV-visible spectra of the organic phase after biphasic reaction (cell II, Scheme 1: TTF $=1 \mathrm{mM}, \mathrm{pH}=2$ ). (Inset) Analysis of the UV-visible spectroscopic data. (b) Comparison of the evolution of the reaction at $\mathrm{pH}=1$ and at $\mathrm{pH}=2$.

order of reaction with respect to neutral TTF with the $\mathrm{pH}$ confirms that the reaction is not elementary. It is clear that the rate of the reaction increases as the concentration of protons increases (Figure $3 \mathrm{~b}$ ), confirming the rate law proposed in eq 8.

The dependence of the reaction on the TTF concentration was also confirmed using cell 2, Scheme 1 (Figure 4). The order of reaction with respect to the concentration of TTF was determined to be 1 , and the rate constant, $8.2 \times 10^{-4}$, which corroborates the order estimated from Figure $3(\mathrm{pH}=2)$.

The product of the reaction between oxygen and TTF was studied by ion transfer voltammetry using the four-electrode cell illustrated in Scheme 2 in which, the transfer of protons from the aqueous to the organic phase is driven by applying a positive potential, turning the reaction much slower. Even though for the neutral TTF no signals were expected, a signal with standard transfer potential of $-0.02 \mathrm{~V}$ (Figure $5 \mathrm{a}$ ) was observed indicating that the reactant was partially oxidized which indeed can be also observed in the UV-visible spectra (Figure 1). No shift of the signal with the $\mathrm{pH}$ was observed indicating this signal does not correspond to the assisted proton transfer by TTF to form $\mathrm{TTFH}^{+}$but to the transfer of the radical cation $\mathrm{TTF}^{\circ+}$. The increase of the current when the $\mathrm{pH}$ decreases indicates that the formation of the product of the reaction depends on the $\mathrm{pH}$ that is in accordance with the proposed mechanism and with the results shown in Figure $3 \mathrm{~b}$. Figure $5 \mathrm{~b}$ shows the scan rate dependence of the transfer of $\mathrm{TTF}^{\circ+}$, showing this process is controlled by linear diffusion. In order to study the transfer of the product obtained after a biphasic reaction using $\mathrm{TB}^{-}$as the common ion, the reaction was carried out during $12 \mathrm{~h}$ (cell II, Scheme 1: TTF $=5 \mathrm{mM}, \mathrm{pH}=2$ ) 


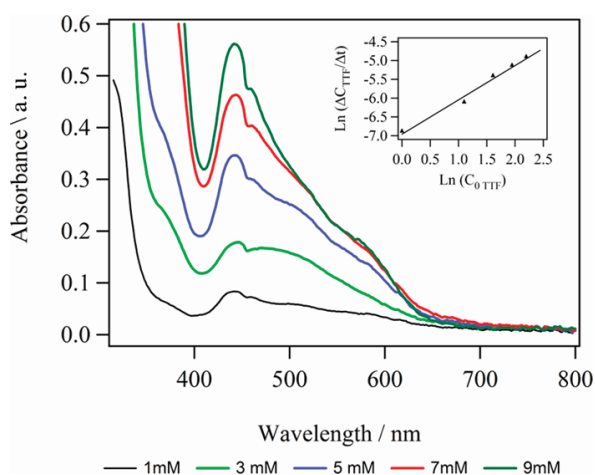

Figure 4. UV-visible spectra of the organic phase after $1 \mathrm{~h}$ of biphasic reaction at different initial concentration of TTF (cell II, Scheme 1: $\mathrm{pH}=2$ ) under aerobic conditions.

and then the organic phase (diluted 10 times) was analyzed using the four-electrode cell (Figure 5c). The standard transfer potential of the product was found to be also $-0.02 \mathrm{~V}$, which confirms that the voltammetric signal corresponds to the transfer of $\mathrm{TTF}^{\circ+}$ formed after reaction with oxygen.

In order to determine whether TTF could achieve the twoelectron reduction of oxygen, the aqueous phase was treated with sodium iodide and analyzed by UV-visible spectroscopy. The obtained spectrum shows the signals corresponding to the oxidation of $\mathrm{I}^{-}$to $\mathrm{I}_{3}^{-}$by hydrogen peroxide. ${ }^{37}$ Considering the amount of TTF that has been consumed during the biphasic reaction, the concentration of $\mathrm{H}_{2} \mathrm{O}_{2}$ was estimated as less than $3 \%$ of the expected value from eq 6 . This result suggests two possibilities: (i) TTF leads to the two-electron reduction of $\mathrm{O}_{2}$ into $\mathrm{H}_{2} \mathrm{O}_{2}$, which is in turn being reduced either by TTF or $\mathrm{TTFH}^{+}$, or (ii) $97 \%$ of the consumed TTF is involved in the fourelectron reduction following eq 7. To test the first reaction pathway, a biphasic reaction between $10 \mathrm{mM} \mathrm{H}_{2} \mathrm{O}_{2}$ and $1 \mathrm{mM}$ TTF was performed (cell II, Scheme 1: TTF $=1 \mathrm{mM}, \mathrm{pH}=2$ ) under anaerobic conditions. After a 3 -h reaction, the UV-visible spectrum of the organic phase (Figure S2, SI) does not differ from the spectrum taken without $\mathrm{H}_{2} \mathrm{O}_{2}$ in the same conditions (no increase of the signals corresponding to $\mathrm{TTF}^{\circ+}$ ), indicating that hydrogen peroxide is reduced neither by TTF nor by $\mathrm{TTFH}^{+}$. This experiment clearly indicates that under aerobic conditions TTF reduces oxygen directly into water.

As TTF alone can transfer at most two electrons and protons are also needed, we investigated the aggregation of TTF and $\mathrm{TTFH}^{+}$into dimers and tetramers by electronic structure computations. As expected, $\left(\mathrm{TTFH}^{+}\right)_{2}$ is not bound due to the strong Coulombic repulsion between the two positive charges. In principle, counterions could help overcome this repulsion and favor the dimer formation. The large $\mathrm{TB}^{-}$anion has, however, a very low coordinating power and charge density due to its size. As evidenced by the crystal structure of $\left(\mathrm{TTFH}^{+}\right)\left(\mathrm{BF}^{-}\right)^{71}$ obtained from the CSD database, ${ }^{72}$ no specific interactions between two $\mathrm{TTFH}^{+}$units could be determined. Counterion-cation $\left(\mathrm{TTFH}^{+}\right)_{2}\left(\mathrm{BF}^{-}\right)_{2}$ complexes were further analyzed computationally showing that the most stable complex exhibit cation-anion electrostatic interactions rather than direct interactions between the two TTFH ${ }^{+}$units (Figure S3, SI). Note that in the presence of the larger and less coordinating $\mathrm{TB}^{-}$, even less interaction is expected between the TTF units. In contrast, the TTF-TTFH ${ }^{+}$ dimer is stabilized by $-5.1 \mathrm{kcal} / \mathrm{mol}(-8.2 \mathrm{kcal} / \mathrm{mol})$ relative to
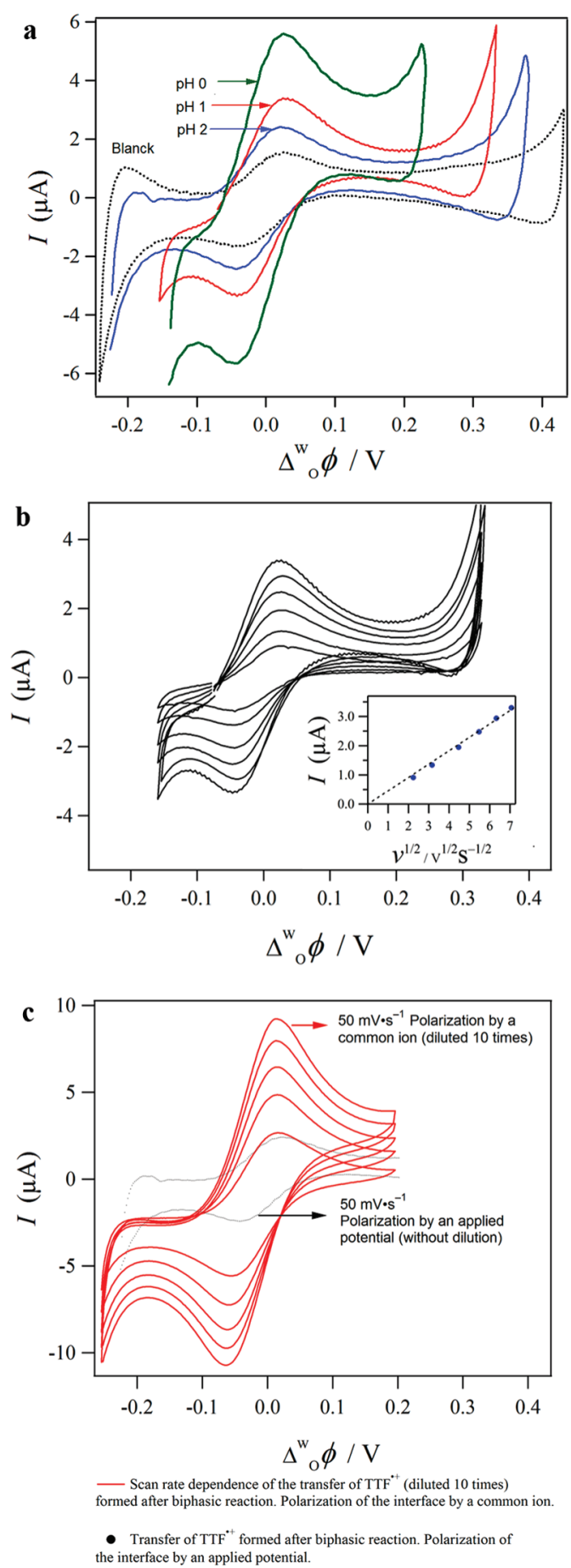

Figure 5. Ion transfer voltammograms obtained by using the system illustrated in Scheme 2 (5 mM TTF); (a) pH dependence; (b) scan rate dependence at $\mathrm{pH}=1$; (c) transfer of the $\mathrm{TTF}^{\circ+}$ formed after biphasic reaction $\left(12 \mathrm{~h}\right.$ ) using the common ion $\mathrm{TB}^{-}$(cell II, Scheme 1: $5 \mathrm{mM}$ $\mathrm{TTF}, \mathrm{pH}=2$ ). The organic phase was diluted 10 times prior to ion transfer analyisis.

its monomers at the B3LYP-dDsC/6-31+G* (M06-2X/ccpVTZ) level including continuum solvation (Figure 6).

Two such dimers can gain an additional $4.0 \mathrm{kcal} / \mathrm{mol}(5.1 \mathrm{kcal} /$ $\mathrm{mol}$ ) at B3LYP-dDsC/6-31+G** (M06-2X/cc-pVTZ) with implicit solvation by assembling through their TTF moieties, thereby forming a helical tetramer $\left[\mathrm{TTF}_{4} \mathrm{H}_{2}\right]^{2+}$ (displayed in Figure $7 \mathrm{a}$ 


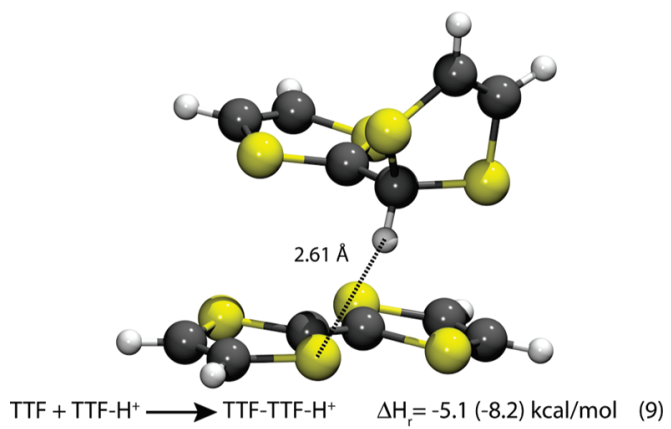

Figure 6. $\mathrm{TTF}-\mathrm{TTFH}^{+}$dimer geometry and binding enthalpy at 298 $\mathrm{K}$, computed at the B3LYP-dDsC/6-31+G**//B3LYP-dDsC/6-31G** level (M06-2X/cc-pVTZ//M06-2X/SVP number in parentheses) with continuum solvation.

together with $\mathrm{O}_{2}$ ). This tetramer is potentially able to deliver the four electrons needed for the reduction of oxygen to water.

The potential energy surface of the $\left[\mathrm{TTF}_{4} \mathrm{H}_{2} \cdots \mathrm{O}_{2}\right]^{2+}$ complex is very flat as exemplified by the small binding energies computed for the two minima located (conformers A and B, Figure $7 \mathrm{a}$, see also Table 1 ). The dioxygen molecule binds weakly to $\left[\mathrm{TTF}_{4} \mathrm{H}_{2}\right]^{2+}$ at the M06-2X/cc-pVTZ level $(-0.3$ to -0.1 $\mathrm{kcal} / \mathrm{mol}$ ) but not at B3LYP-dDsC $/ 6-31+\mathrm{G}^{* *}$ for which the complex (Figure $7 \mathrm{a}$ ) is $0.4-1.2 \mathrm{kcal} / \mathrm{mol}$ less stable than the optimized isolated monomers (only once implicit solvation and basis set superposition corrections are included, see Table 1). The barrier associated with a hydrogen atom (not a proton) transfer (Figure $7 \mathrm{~b}$ ) is $21.2 \mathrm{kcal} / \mathrm{mol}(30.5 \mathrm{kcal} / \mathrm{mol}$ ) (Figure 8$)$. This relatively high barrier is in agreement with the slow reaction observed experimentally. The complex (triplet electronic state) obtained after $\mathrm{H}$ atom transfer, $\left[\mathrm{TTF}_{4} \mathrm{H} \cdots \mathrm{HO}_{2}\right]^{2+}$, is only marginally destabilized $\left(1.5 \mathrm{kcal} / \mathrm{mol}\right.$ at $\mathrm{B} 3 \mathrm{LYP}-\mathrm{dDsC} / 6-31+\mathrm{G}^{* *}$ and $2.8 \mathrm{kcal} / \mathrm{mol}$ at $\mathrm{M} 06-2 \mathrm{X} / \mathrm{cc}-\mathrm{pVTZ}$ with implicit solvent) as compared to the starting $\left[\mathrm{TTF}_{4} \mathrm{H}_{2} \cdots \mathrm{O}_{2}\right]^{2+}$ adduct. It is likely that the highly reactive $\mathrm{HO}_{2}{ }^{\bullet}$ species reacts further with $\left[\mathrm{TTF}_{4} \mathrm{H}\right]^{\bullet 2+} . \mathrm{HO}_{2}{ }^{\bullet}$ and the $\mathrm{TTF}^{\bullet+}$ moieties within the tetramer could for instance combine to form an intermediate (Figure S4, SI), which could then dissociate from the tetramer and get the needed protons and electrons to form two molecules of water from individual TTFH ${ }^{+}$units in solution. From the TTF$\mathrm{HO}_{2}$ intermediate, other paths can be envisioned, leading to $\mathrm{H}_{2} \mathrm{O}_{2}$ or TTF decomposition. However, there is no experimental evidence supporting those paths.

In order to confirm the formation of water during the reduction of oxygen by TTF, ${ }^{1} \mathrm{H}$ NMR analyses were performed in DCE- $d_{4}$ containing $5 \mathrm{mM}$ TTF+BATB and dried HTB+BATB. The dried HTB was obtained using the system illustrated in Scheme 3 following the procedure described in the Experimental Section. Spectra a and b of Figure S5 (SI) display the ${ }^{1} \mathrm{H}$ NMR spectra of $\mathrm{HTB}+5 \mathrm{mM}$ BATB and $5 \mathrm{mM}$ TTF+5 mM BATB, respectively, both of them dissolved in DCE- $d_{4}$. In Figure S5b (SI) the signal at $\delta=1.6 \mathrm{ppm}$ corresponds to the four protons conforming TTF. Figure S6 (SI) shows the ${ }^{1} \mathrm{H}$ NMR spectra obtained after $2,5,8$, and 24 h of reaction.

Comparing the ${ }^{1} \mathrm{H}$ NMR spectra in the Figures S5b and S6 (SI), it is clear that the signal corresponding to the protons of TTF completely disappears after reaction with oxygen, and a set of singlet signals appears at $\delta=6.15,6.25$, and $8.75 \mathrm{ppm}$ with a integration ratio of $2: 1: 2$, which are consistent with the reported values for $\mathrm{TTFH}^{+}$, being the signal at $\delta=8.75 \mathrm{ppm}$ (low field) a
Conformer A

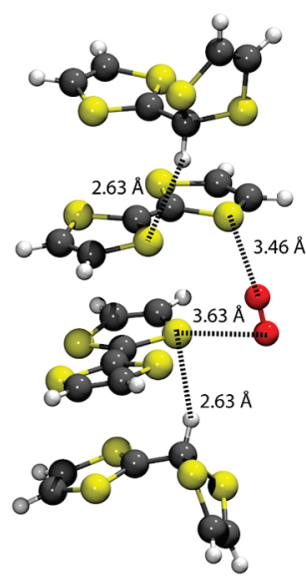

TTF-TTF- $\mathrm{H}^{+} \longrightarrow\left[\mathrm{TTF}_{4} \mathrm{H}_{2}\right]^{2+}$

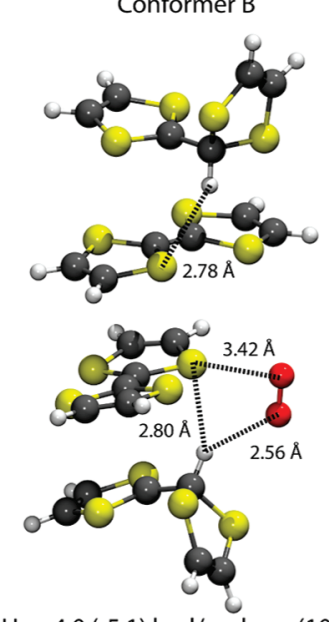

(10)

$\left[\mathrm{TTF}_{4} \mathrm{H}_{2}\right]^{2+}+\mathrm{O}_{2} \longrightarrow\left[\mathrm{TTF}_{4} \mathrm{H}_{2} \cdots \mathrm{O}_{2}\right]^{2+}(\mathrm{B}) \quad \Delta \mathrm{H}_{\mathrm{r}}=+0.4(-0.1) \mathrm{kcal} / \mathrm{mol}$

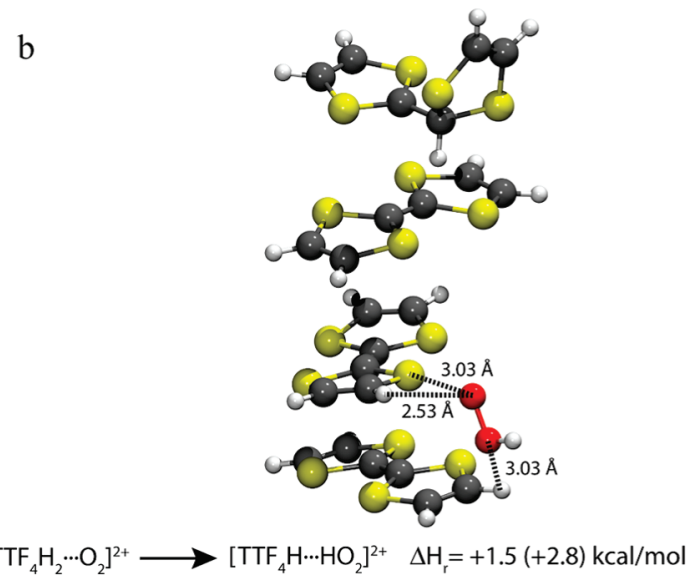

Figure 7. (a) $\left[\mathrm{TTF}_{4} \mathrm{H}_{2} \cdots \mathrm{O}_{2}\right]^{2+}$ helical complex geometries A and $\mathrm{B}$; (b) $\left[\mathrm{TTF}_{4} \mathrm{H} \cdots \mathrm{HO}_{2}\right]^{2+}$ complex geometry. Reaction enthalpies at 298 $\mathrm{K}$ computed at the B3LYP-dDsC/6-31+G**//B3LYP-dDsC/6-31G** level (M06-2X/cc-pVTZ//M06-2X/SVP numbers in parentheses) with continuum solvation.

the one that corresponds to the protons of the positively charged ring (eq 3). ${ }^{24,70}$ However, those signals could also be related to the protons in the protonated tetramer. The similarity between the NMR spectrum of $\mathrm{TTFH}^{+}$and of the protonated tetramer (Figure 7a) is supported by computations of chemical shifts at B3LYP/6-311+G(2d,p) level on the M06-2X/SVP geometry. Three signals in line with experiment are obtained for the $\mathrm{TTFH}^{+}$monomer, namely two protons at $8.6 \mathrm{ppm}$ (from the charged ring), two protons at $6.0-6.1 \mathrm{ppm}$, and one proton at $6.5 \mathrm{ppm}$. The spectrum computed for $\mathrm{TTFH}^{+}$in the tetramer reveals essentially the same signals, although slightly shifted at 8.4-8.2 ppm for the charged ring protons, 6.1-6.3 ppm for the neutral ring protons, and $5.3 \mathrm{ppm}$ for the last proton. The signal corresponding to the proton on the central $\mathrm{C}-\mathrm{C}$ bond shifts from $6.5 \mathrm{ppm}$ in the monomer to $5.3 \mathrm{ppm}$ in the tetramer. This shift could be due to the proximity of the proton to the electronrich $S$ atoms in the tetramer geometry (Figure 7a). These signals disappear progressively with time, confirming that either $\mathrm{TTFH}^{+}$ or the helical tetramer is the intermediate in the oxygen reduction reaction; therefore, they support the mechanisms proposed in 
Table 1. Reaction Energies and Barrier for the Computed Path, with Effect of Including a Solvation Model, Thermal and BSSE Corrections

\begin{tabular}{|c|c|c|c|c|c|c|c|c|}
\hline reactions & M06- $2 \mathrm{X}^{a}$ & thermal $^{b}$ & solvent $^{c}$ & $\mathrm{BSSE}^{d}$ & $\mathrm{dDsC}^{e}$ & thermal $^{f}$ & solvent ${ }^{g}$ & $\mathrm{BSSE}^{h}$ \\
\hline reaction 9 & -24.0 & -22.9 & -9.2 & -8.2 & -21.4 & -20.2 & -7.7 & -5.1 \\
\hline reaction 10 & 9.6 & 10.7 & -6.6 & -5.1 & 19.9 & 21.2 & -7.5 & -4.0 \\
\hline reaction $11 \mathrm{a}$ & -3.3 & -2.6 & -1.4 & -0.3 & -2.2 & -2.5 & -0.04 & 1.2 \\
\hline reaction $11 b$ & -3.4 & -2.6 & -1.2 & -0.1 & -2.4 & -2.7 & -0.9 & 0.4 \\
\hline barrier $^{i}$ & 34.5 & 30.7 & 30.5 & 30.5 & 24.1 & 21.6 & 21.2 & 21.2 \\
\hline reaction $12^{i}$ & 2.8 & 1.9 & 2.8 & 2.8 & -1.1 & -0.6 & 1.5 & 1.5 \\
\hline
\end{tabular}

${ }^{a}$ M06-2X/SVP, gas phase. ${ }^{b} \mathrm{M} 06-2 \mathrm{X} / \mathrm{SVP}$, gas phase with thermal enthalpic corrections. ${ }^{c} \mathrm{M} 06-2 \mathrm{X} / \mathrm{cc}-\mathrm{pVTZ}$ with implicit solvation and thermal enthalpic corrections. ${ }^{d} \mathrm{M} 06-2 \mathrm{X} / \mathrm{cc}-\mathrm{pVTZ}$ with implicit solvation, thermal enthalpic and BSSE corrections. ${ }^{e} \mathrm{~B} 3 \mathrm{LYP}-\mathrm{dDsC} / 6-31+\mathrm{G}^{* *}$, gas phase. ${ }^{f} \mathrm{~B} 3 \mathrm{LYP}-\mathrm{dDsC} / 6-31+\mathrm{G}^{* *}$, gas phase with thermal enthalpic corrections. ${ }^{g} \mathrm{~B} 3 \mathrm{LYP}-\mathrm{dDsC} / 6-31+\mathrm{G}^{* *}$ with implicit solvation and thermal enthalpic corrections. ${ }^{h}$ B3LYP-dDsC/6-31+G $\mathrm{G}^{* *}$ with implicit solvation, thermal enthalpic and BSSE corrections. ${ }^{i}$ Energies computed with conformer B as a reference, thermal contribution and BSSE correction from conformer A.

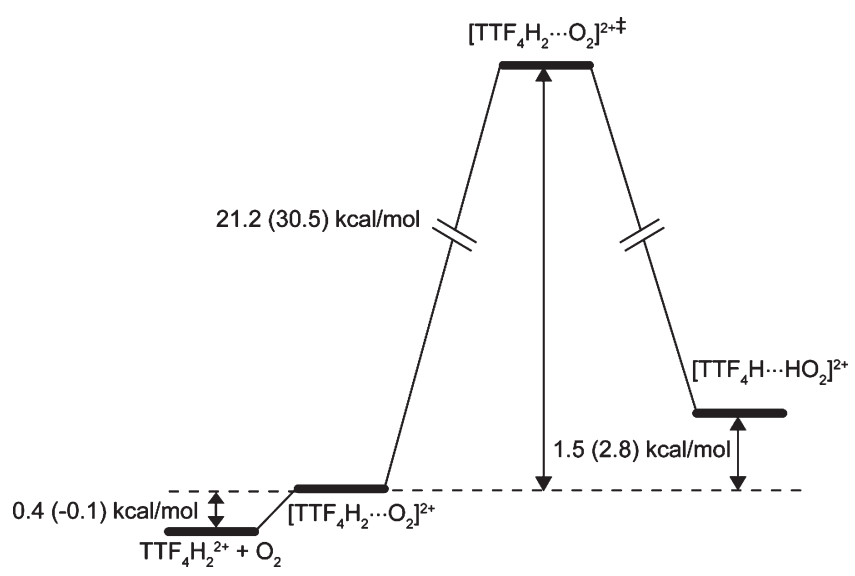

Figure 8. Computed reaction pathway, enthalpies at $298 \mathrm{~K}$ computed at B3LYP-dDsC/6-31+G**//B3LYP-dDsC/6-31G ${ }^{* *}$ (M06-2X/cc$\mathrm{pVTZ//M06-2X/SVP} \mathrm{numbers} \mathrm{in} \mathrm{parentheses)} \mathrm{with} \mathrm{continuum}$ solvation. Conformer B (Figure 7a) is taken as the reference for energies computations. Thermal contribution and BSSE correction is from conformer A.

this work. It is important to note that the chemical shift of TTF in DCE- $d_{4}(\delta=1.6 \mathrm{ppm})$ is significantly different from the one obtained in other solvents such as chloroform $(\delta=6 \mathrm{ppm})$ as we have probed experimentally and as reported by others. 17,70

In order to probe that any increase in water is due to the reaction between TTF and oxygen instead of absorption of water, the blanks of HTB+BATB (blank 1) and TTF+BATB (blank 2) were analyzed every time the reaction mixture was analyzed (Figure $\mathrm{S} 5 \mathrm{a}, \mathrm{b}, \mathrm{SI})$. Since $\mathrm{BA}^{+}$does not change during the reaction, the content of water was estimated by relating the integration of the protons of $\mathrm{BA}^{+}$at $\delta=7.45 \mathrm{ppm}$ (corresponding to 6 protons) with the integration of the peak of water. The chemical shift of water is different in the two blanks ( $\delta=4.1 \mathrm{ppm}$ in blank 1 and $\delta=6.4 \mathrm{ppm}$ in blank 2) as well as in the mixture of reaction $(\delta=2.5-3 \mathrm{ppm})$, which is because the chemical shift of water is strongly dependent on several factors as the temperature and the $\mathrm{pH}$. The signals at $\delta=1.15$ and $\delta=7 \mathrm{ppm}$ correspond to toluene that remained after the azeotropic drying. The content of water in the blanks remained constant with time, indicating the solutions do not absorb water from the environment and that the compounds are stable. These values were subtracted from the content of water determined in the mixture of reaction (Figure S6, SI) in order to estimate the increase of water due to the reaction.
In this way, it was determined that after 2, 5, 8, and $24 \mathrm{~h}$ of reaction there is an increase of water around 22, 25, 28 and $38 \%$, respectively, with respect to the blanks. Taking the concentration of $\mathrm{BA}^{+}(5 \mathrm{mM})$ as reference (since all the integrations were made with respect to $\mathrm{BA}^{+}$), the concentration of water was estimated to be around $5,6,7$, and $8.5 \mathrm{mM}$, respectively. However, it is important to remark that these values are an approximation since the integration of water from the HTB blank could not be exactly determined (the signal of water is partially overlapped by the integration of the protons of DCE). These results confirm that TTF is reacting with oxygen to produce water since, in accordance with eqs 5 and 7 , if the initial concentration of TTF is $5 \mathrm{mM}$, the expected concentration of water after reaction is $7.5 \mathrm{mM}$.

\section{CONCLUSIONS}

The reduction of oxygen by TTF at liquid-liquid interfaces has been studied. Spectroscopy, voltammetry, and ${ }^{1} \mathrm{H}$ NMR analysis show that the reaction proceeds by fast protonation of TTF followed by the direct four-electron reduction of oxygen to water. On the basis of electronic structure computations, we postulate the formation of stable helical tetramers from dimers between neutral and protonated TTF molecules. Such a protonated tetramer is potentially able to deliver the four electrons needed for the oxygen reduction.

\section{ASSOCIATED CONTENT}

S Supporting Information. Cyclic voltammogram at $\mathrm{Pt}$ microelecrode in the bulk of an organic solution containing 5 $\mathrm{mm}$ TTF and $5 \mathrm{mM}$ BATB; UV-visible spectra of the organic phase after a biphasic reaction between $\mathrm{H}_{2} \mathrm{O}_{2}$ and TTF under anaerobic conditions; optimized $\left(\mathrm{TTFH}^{+}\right)_{2}\left(\mathrm{BF}^{-}\right)_{2}$ complex at M06-2X/SVP level; optimized adduct of $\mathrm{HO}_{2}{ }^{\bullet}$ on $\mathrm{TTF}^{\bullet+}$ at M062X/SVP level; ${ }^{1} \mathrm{H}$ NMR spectra of the blanks of HTB and TTF and the mixture of reaction after 2, 5, 8, and $24 \mathrm{~h}$; M06-2X energies for all species; B3LYP-dDsC energies for all species; $X Y Z$ coordinates for all stationary points; and complete references 26,50 , and 51. This material is available free of charge via the Internet at http:// pubs.acs.org.

\section{AUTHOR INFORMATION}

\section{Corresponding Author}

hubert.girault@epfl.ch 


\section{ACKNOWLEDGMENT}

We thank the Swiss Science Foundation, the NCCR MUST, the Sandoz family foundation, the Swiss NSF Grant No. 200021 $121577 / 1$, and EPFL for financial support. Fabrice Avaltroni is acknowledged for providing the script for the random conformational search.

\section{REFERENCES}

(1) Decreau, R. A.; Collman, J. P.; Hosseini, A. Chem. Soc. Rev. 2010, 39, 1291-1301.

(2) Collman, J. P.; Wagenknecht, P. S.; Hutchison, J. E. Angew. Chem., Int. Ed. Engl. 1994, 33, 1537-1554.

(3) Collman, J. P.; Fu, L.; Herrmann, P. C.; Zhang, X. Science 1997, 275, 949-951.

(4) Ferguson-Miller, S.; Babcock, G. T. Chem. Rev. 1996, 96, 2889-2908.

(5) Volkov, A. G.; Gugeshashvili, M. I.; Deamer, D. W. Electrochim. Acta 1995, 40, 2849-2868.

(6) Collman, J. P.; Denisevich, P.; Konai, Y.; Marrocco, M.; Koval, C.; Anson, F. C. J. Am. Chem. Soc. 1980, 102, 6027-6036.

(7) Collman, J. P.; Anson, F. C.; Barnes, C. E.; Bencosme, C. S.; Geiger, T.; Evitt, E. R.; Kreh, R. P.; Meier, K.; Pettman, R. B. J. Am. Chem. Soc. 1983, 105, 2694-2699.

(8) Collman, J. P.; Hendricks, N. H.; Kim, K.; Bencosme, C. S. J. Chem. Soc., Chem. Commun. 1987, 1537-1538.

(9) Collman, J. P.; Hutchison, J. E.; Lopez, M. A.; Tabard, A.; Guilard, R.; Seok, W. K.; Ibers, J. A.; L’Her, M. J. Am. Chem. Soc. 1992, 114, 9869-9877.

(10) Shi, C.; Steiger, B.; Yuasa, M.; Anson, F. C. Inorg. Chem. 1997, 36, 4294-4295.

(11) Durand, R. R., Jr; Bencosme, C. S.; Collman, J. P.; Anson, F. C. J. Am. Chem. Soc. 1983, 105, 2710-2718.

(12) Ngameni, E.; Le Mest, Y.; L’Her, M.; Collman, J. P.; Hendricks, N. H.; Kim, K. J. Electroanal. Chem. 1987, 220, 247-257.

(13) Chang, C. J.; Loh, Z.-H.; Shi, C.; Anson, F. C.; Nocera, D. G. J. Am. Chem. Soc. 2004, 126, 10013-10020.

(14) Guilard, R.; Brandes, S.; Tardieux, C.; Tabard, A.; L'Her, M.; Miry, C.; Gouerec, P.; Knop, Y.; Collman, J. P. J. Am. Chem. Soc. 1995, 117, 11721-11729.

(15) McGuire, R., Jr; Dogutan, D. K.; Teets, T. S.; Suntivich, J.; Shao-Horn, Y.; Nocera, D. G. Chem. Sci. 2010, 1, 411-414.

(16) Ndamanisha, J. C.; Bo, X.; Guo, L. Analyst 2010, 135, 621-629.

(17) Giffard, M.; Gorgues, A.; Riou, A.; Roncali, J.; Alonso, P.; Uriel, S.; Garín, J.; Nguyen, T. P. Synth. Met. 1995, 70, 1133-1134.

(18) Bigot, J.; Charleux, B.; Cooke, G.; Delattre, F.; Fournier, D.; Lyskawa, J.; Sambe, L.; Stoffelbach, F. o.; Woisel, P. J. Am. Chem. Soc. 2010, 132, 10796-10801.

(19) Sun, W.; Xu, C.-H.; Zhu, Z.; Fang, C.-J.; Yan, C.-H. J. Phys. Chem. C 2008, 112, 16973-16983.

(20) Halling, M. D.; Bell, J. D.; Pugmire, R. J.; Grant, D. M.; Miller, J. S. J. Phys. Chem. A 2010, 114, 6622-6629.

(21) Williams, J. M.; Schultz, A. J.; Geiser, U.; Carlson, K. D.; Kini, A. M.; Wang, H. H.; Kwok, W.-K.; Whangbo, M.-H.; Schirber, J. E. Science 1991, 252, 1501-1508.

(22) Akutagawa, T.; Kakiuchi, K.; Hasegawa, T.; Noro, S.-i.; Nakamura, T.; Hasegawa, H.; Mashiko, S.; Becher, J. Angew. Chem., Int. Ed. 2005, 44, 7283-7287.

(23) Guldi, D. M.; Sanchez, L.; Martin, N. J. Phys. Chem. B 2001, 105, 7139-7144.

(24) Kobayashi, Y.; Yoshioka, M.; Saigo, K.; Hashizume, D.; Ogura, T. J. Am. Chem. Soc. 2009, 131, 9995-10002.

(25) Wenger, S.; Bouit, P.-A.; Chen, Q.; Teuscher, J.; Censo, D. D.; Humphry-Baker, R.; Moser, J.-E.; Delgado, J. L.; Martin, N.; Zakeeruddin, S. M.; Grätzel, M. J. Am. Chem. Soc. 2010, 132, 5164-5169.

(26) Spruell, J. M.; et al. Nature Chem. 2010, 2, 870-879.
(27) Wudl, F.; Smith, G. M.; Hufnagel, E. J. J. Chem. Soc., Chem. Commun. 1970, 1453-1454.

(28) Ziganshina, A. Y.; Ko, Y. H.; Jeon, W. S.; Kim, K. Chem. Commun. 2004, 806-807.

(29) Partovi-Nia, R.; Su, B.; Li, F.; Gros, C. P.; Barbe, J. M.; Samec, Z.; Girault, H. H. Chem.-Eur. J. 2009, 15, 2335-2340.

(30) Trôjanek, A.; Langmaier, J.; Samec, Z. Electrochem. Commun. 2006, 8, 475-481.

(31) Su, B.; Hatay, I.; Li, F.; Partovi-Nia, R.; Méndez, M. A.; Samec, Z.; Ersoz, M.; Girault, H. H. J. Electroanal. Chem. 2010, 639, 102-108.

(32) Méndez, M.; Partovi-Nia, R.; Ge, P.; Olaya, A.; Hojeij, M.; Girault, H. H. Phys. Chem. Chem. Phys. 2010, 12, 15163-15171.

(33) Li, F.; Su, B.; Salazar, F. C.; Nia, R. P.; Girault, H. H. Electrochem. Commun. 2009, 11, 473-476.

(34) Su, B.; Hatay, I.; Trojanek, A.; Samec, Z.; Khoury, T.; Gros, C. P.; Barbe, J. M.; Daina, A.; Carrupt, P. A.; Girault, H. H. J. Am. Chem. Soc. 2010, 132, 2655-2662.

(35) Hatay, I.; Su, B.; Méndez, M. A.; Corminboeuf, C.; Khoury, T.; Gros, C. P.; Bourdillon, M.; Meyer, M.; Barbe, J.-M.; Ersoz, M.; Zàlis, S.; Samec, Z.; Girault, H. H. J. Am. Chem. Soc. 2010, 132, 13733-13741.

(36) Olaya, A. J.; Méndez, M. A.; Cortés-Salazar, F.; Girault, H. H. J. Electroanal. Chem. 2010, 644, 60-66.

(37) Hatay, I.; Su, B.; Li, F.; Méndez, M. A.; Khoury, T.; Gros, C. P.; Barbe, J. M.; Ersoz, M.; Samec, Z.; Girault, H. H. J. Am. Chem. Soc. 2009, 131, 13453-13459.

(38) Zhao, Y.; Truhlar, D. Theor. Chem. Acc. (Theor. Chim. Acta) 2008, 120, 215-241.

(39) Steinmann, S. N.; Corminboeuf, C. J. Chem. Theory Comput. 2010, 6, 1990-2001.

(40) Steinmann, S. N.; Corminboeuf, C. J. Chem. Phys. 2011, 134 (4), 044117, 10.1063/1.3545985.

(41) Becke, A. D. J. Chem. Phys. 1993, 98, 5648-5652.

(42) Lee, C.; Yang, W.; Parr, R. G. Phys. Rev. B 1988, 37, 785.

(43) Dunning, J.; Thom, H. J. Chem. Phys. 1989, 90, 1007-1023.

(44) Woon, D. E.; Dunning, J.; Thom, H. J. Chem. Phys. 1993, 98, 1358-1371.

(45) Schafer, A.; Horn, H.; Ahlrichs, R. J. Chem. Phys. 1992, 97, 2571-2577.

(46) Hariharan, P. C.; Pople, J. A. Theor. Chim. Acta 1973, $28,213-222$.

(47) Hehre, W. J.; Ditchfield, R.; Pople, J. A. J. Chem. Phys. 1972, $56,2257-2261$

(48) Francl, M. M.; Pietro, W. J.; Hehre, W. J.; Binkley, J. S.; Gordon, M. S.; DeFrees, D. J.; Pople, J. A. J. Chem. Phys. 1982, 77, 3654-3665.

(49) Frisch, M. J.; Pople, J. A.; Binkley, J. S. J. Chem. Phys. 1984, $80,3265-3269$.

(50) Shao, Y.; et al. Phys. Chem. Chem. Phys. 2006, 8, 3172.

(51) Frisch, M. J.; et al. Gaussian 09, Revision B.01; Gaussian Inc.: Wallingford CT, 2009.

(52) Marenich, A. V.; Olson, R. M.; Kelly, C. P.; Cramer, C. J.; Truhlar, D. G. J. Chem. Theory Comput. 2007, 3, 2011-2033.

(53) Wheeler, S. E.; Houk, K. N. J. Chem. Theory Comput. 2010, 6, 395-404.

(54) Tomasi, J.; Mennucci, B.; Cammi, R. Chem. Rev. 2005, 105, 2999-3094.

(55) Bauernschmitt, R.; Ahlrichs, R. J. Chem. Phys. 1996, 104, 9047-9052.

(56) Seeger, R; Pople, J. A. J. Chem. Phys. 1977, 66, 3045-3050.

(57) Boys, S. F.; Bernardi, F. Mol. Phys. 1970, 19, 553-566.

(58) Cheeseman, J. R.; Trucks, G. W.; Keith, T. A.; Frisch, M. J. J. Chem. Phys. 1996, 104, 5497-5509.

(59) Wolinski, K.; Hinton, J. F.; Pulay, P. J. Am. Chem. Soc. 1990, $112,8251-8260$.

(60) Clark, T.; Chandrasekhar, J.; Spitznagel, G. W.; Schleyer, P. V. R. J. Comput. Chem. 1983, 4, 294-301.

(61) Krishnan, R.; Binkley, J. S.; Seeger, R.; Pople, J. A. J. Chem. Phys. 1980, 72, 650-654.

(62) McLean, A. D.; Chandler, G. S. J. Chem. Phys. 1980, 72, 5639-5648. 
(63) Addicoat, M. A.; Metha, G. F. J. Comput. Chem. 2009, 30, 57-64.

(64) Avaltroni, F.; Corminboeuf, C. J. Comput. Chem. 2011, 32, 1869-1875.

(65) Saunders, M. J. Comput. Chem. 2004, 25, 621-626.

(66) Torrance, J. B.; Scott, B. A.; Welber, B.; Kaufman, F. B.; Seiden, P. E. Phys. Rev. B 1979, 19, 730.

(67) Aprahamian, I.; Olsen, J.-C.; Trabolsi, A.; Stoddart, J. F. Chem.Eur. J. 2008, 14, 3889-3895.

(68) Khodorkovsky, V.; Shapiro, L.; Krief, P.; Shames, A.; Mabon, G.; Gorgues, A.; Giffard, M. Chem. Commun. 2001, 2736-2737.

(69) Yoshizawa, M.; Kumazawa, K.; Fujita, M. J. Am. Chem. Soc. 2005, 127, 13456-13457.

(70) Giffard, M.; Alonso, P.; GarÌn, J.; Gorgues, A.; Nguyen, T. P.; Richomme, P.; Robert, A.; Roncali, J.; Uriel, S. Adv. Mater. 1994, 6, 289-300.

(71) Giffard, M.; Frere, P.; Gorgues, A.; Riou, A.; Roncali, J.; Toupet, L. J. Chem. Soc., Chem. Commun. 1993, 944-945.

(72) Allen, F. Acta Crystallogr., Sect. B 2002, 58, 380-388. 